\title{
The EU's Competence Gap in Public Health and Non-Communicable Disease Policy
}

\author{
Oliver Bartlett
}

\begin{abstract}
The European Union (EU) has had a Treaty competence in the field of public health since 1993, however the slow development of this competence has not kept up with the rate at which the EU's policy ambitions in public health have developed, especially in the field of non-communicable disease (NCD) prevention. This has led the EU to rely on alternative legal bases in order to realise these ambitions, leading to a 'competence gap' between the legal bases that authorise EU action on NCD prevention and the policies the EU would like to pursue.

This paper will explore, in three stages, how this competence gap might be addressed. First, it will examine the arguments for and against giving the EU public health competences. Second, it will analyse the EU's specific public health competence in Article 168 of the Treaty on the Functioning of the European Union (TFEU) and the general internal market harmonisation competence in Article 114 TFEU, in order to explore the precise boundaries of each competence as legal bases for EU public health action. Third, it will explore the legal relationship between Articles 168 and 114 and explain why, despite a more powerful specific public health competence being a theoretically neat solution to the competence gap, the likelihood of the EU being given increased public health powers is low.
\end{abstract}

\section{Keywords}

Public health, Non-communicable diseases, EU public health competences

\section{Introduction}

Under the principle of conferral expressed in Article 5(2) of the Treaty on European Union (TEU), the European Union (EU or Union) must be able to identify specific

* Lecturer in Law, Liverpool School of Law and Social Justice; PhD Candidate, Durham Law School (UK).

The author would like to thank the anonymous reviewers for their constructive and helpful comments on an earlier draft of this article. All mistakes and misinterpretations are the sole responsibility of the author. 
powers or competences conferred upon it by the EU Treaties in order to adopt legal acts. If the EU cannot show that the power to adopt a legal act has been conferred upon it, then, in accordance with Article 4 TEU, that competence remains with the Member States. The EU has possessed powers to act in the field of public health since the Maastricht Treaty entered into force in 1993. ${ }^{2}$ Article 129 EC TEU was enacted to provide a modest complementary competence for the EU to encourage 'cooperation between the Member States (...) and, if necessary, lend support to their action' in the field of public health. ${ }^{3}$ This 'represented a compromise between those governments of Member States who did not want any EU mandate in health, and those who wanted to go further."

Even with no formal competence in the area, health concerns were part of EU political activity. Health ministers had been meeting since the 1970s and several European level public health programmes had already been set up-for example, the Europe Against Cancer Programme. ${ }^{5}$ Thus, the granting of competence to the EU might be viewed as either 'setting limits to the expansion of EU-level activities in the public health field,', or as 'little more than a formalization of earlier arrangements. ${ }^{7}$ Either way, from the time that the Maastricht Treaty entered into force onwards, the EU was to have a legal basis upon which to support the actions of the Member States in public health. This competence was updated by the Treaty of Amsterdam, ${ }^{8}$ yet, the new Article 152 EC was not substantively different from the previous provision. The Treaty of Lisbon ${ }^{9}$ updated the competence again, however

1 Consolidated Version of the Treaty on European Union [2008] OJ C115/13 (TEU).

2 Maastricht Treaty [1992] OJ C191/1 (later, the Maastricht Treaty became known formally as the TEU).

3 TEU (n 1) art 129.

4 Tamara Hervey, 'Mapping the Contours of European Union Health Law and Policy' (2002) 8(1) European PL 69, 72.

5 Decision 88/351/EEC of the Council and Representatives of the Governments of the Member States of 21 June 1988 adopting a 1988 to 1989 plan of action for an information and public awareness campaign in the context of the 'Europe against cancer' programme [1988] OJ L160/52.

6 Hervey (n 4) 72.

$7 \quad$ Martin McKee and others, 'The Influence of European Law on National Health Policy' (1996) 6(4) J Eur Social Policy 263, 267.

8 Treaty of Amsterdam Amending the Treaty on European Union, the Treaties Establishing the European Communities and Certain Related Acts [1997] OJ C340/1.

9 Treaty of Lisbon Amending the Treaty on European Union and the Treaty Establishing the European Community [2007] OJ C306/1. 
the latest version-Article 168 Treaty on the Functioning of the European Union $(\mathrm{TFEU})^{10}$-remains complementary.

Although the evolution of the EU's formal competence in public health has therefore been slow, the evolution of its policy ambitions for public health has been far more pronounced. ${ }^{11}$ This is particularly so when it comes to contributing to the prevention of non-communicable diseases (NCDs). NCDs constitute one of the most pressing public health challenges we face today-they account for $86 \%$ of deaths in the World Health Organization (WHO) European Region ${ }^{12}$ and $63 \%$ globally. ${ }^{13}$ This has led to global recognition of the need for action, with the World Health Assembly unanimously approving the Global Action Plan for the Prevention and Control of Noncommunicable Diseases 2013-2020. ${ }^{14}$ The EU has followed suit, expressing the desire to 'accelerate progress on combatting unhealthy lifestyle behaviours. ${ }^{15}$

In this context, the complementary nature of the EU's public health competence is often seen as a hindrance to these ambitions and alternative legal bases are sought. This has created a rather uncomfortable and disjointed relationship between the objectives of the EU with respect to NCD prevention, the competences it possesses in public health, and the competences it actually uses to realise these objectives. I refer to this situation as the EU's competence gap in public health and NCD prevention.

In this paper, I will examine how this competence gap could be addressed. In Section 2, I will examine the arguments for and against giving the EU competence in public health in the first place. In Sections 3 and 4 respectively, I will analyse the C326/47 (TFEU).

11 See Scott Greer and others, 'Health Law and Policy in the European Union' (2013) 381 The Lancet 1135.

12 WHO, 'Action Plan for the Implementation of the European Strategy for the Prevention and Control of Noncommunicable Diseases 2012-2016' (WHO European Office 2012) EUR/ RC61/12, para 6.

13 Political Declaration of the UN high-level Meeting of the General Assembly on the Prevention and Control of Non-communicable Diseases (16 September 2011) A/66/L.1, para 14.

14 WHO, 'Draft action plan for the prevention and control of noncommunicable diseases 20132020’ (6 May 2013) A66/9.

15 Council of the European Union, 'Council Conclusions on Closing Health Gaps within the EU Through Concerted Action to Promote Healthy Lifestyle Behaviours' (9 December 2011) 2011/C359/05, para 9; for more information on the EU's NCD policy ambitions see: Alberto Alemanno \& Amandine Garde, 'The Emergence of an EU Lifestyle Policy: The Case of Alcohol, Tobacco and Unhealthy Diets' (2013) 50(6) CML Rev 1745. 
EU's specific public health competence and its general internal market competence in order to explore the precise boundaries of how each competence might be used by the EU in order to fulfill its role in NCD prevention. In Section 5, I will examine the legal relationship between these two competences and explain why, despite an increase in specific competence being the theoretically neatest solution to the EU's NCD competence gap, the likelihood of greater public health powers being given to the $\mathrm{EU}$ is low.

\section{Should the EU possess competence in public health?}

It should not be taken for granted that the EU should be entitled to act in the field of public health and NCD prevention. Seeking to alter the lifestyles and behaviours of citizens is a controversial use of law-making power for any institution, especially one such as the EU that functions on the basis of conferred powers. As such, opinion is divided on whether the EU should have a public health competence at all. This section will analyse arguments for and against the existence of EU public health powers in order to explore why the EU should be entitled to participate in NCD prevention.

2.1 Arguments against giving the EU powers to intervene in public health

Those who argue that the EU should have limited, if any, power to act in public health do so with fair reason. Member States attempt to 'keep the EU out of a core area of their welfare states' because they are unwilling to allow external interests to influence sensitive national choices regarding how they look after the health of their own nationals. ${ }^{16}$ After all, as the Court of Justice of the European Union (CJEU) first set out in the case of Aragonesa, in the absence of harmonised rules, and within the limits set by general principles of EU law, 'it is for the Member States to decide on the degree of protection which they wish to afford to public health and on the way in which that protection is to be achieved. ${ }^{17}$ (2006) 13(1) J Eur Public Policy 134, 135.

17 Joined Cases C-1/90 and C-176/90 Aragonesa de Publicidad Exterior SA and Publivía SAE v Departamento de Sanidad y Seguridad Social de la Generalitat de Cataluña [1991] ECR I-4179, para 16. 
Several sensible concerns could be said to underlie this principle, for instance, the fact that 'local culture and attitudes influence regulations. ${ }^{18}$ Many practices that can lead to serious public health problems-for example, smoking, drinking, the consumption of particular foods-are an intrinsic part of the vast majority of western cultures. The CJEU has even acknowledged in its jurisprudence concerned with alcohol that consumption of such products is linked to traditional social practices and to local habits and customs', and that this will be liable to affect the interaction of consumers with these products. ${ }^{19}$ Consequently, due to the diversity between Member States in terms of 'the culture and tradition that affect private attitudes ${ }^{20}$ towards these types of lifestyle practices, different and specific pressures on each Member State government will be generated regarding the extent to which citizens approve of government intervention. In such situations, governments do not want their ability to respond sensitively to cultural concerns circumscribed by interference from outsiders who do not understand the particular cultural dynamics at play. From this perspective, it is understandable that Member States are uncomfortable allowing the EU to use its law-making power to intervene in public health matters.

Member States are also unwilling to allow EU intervention in public health due to the EU's perceived lack of institutional capacity properly to understand and act on social concerns, such as public health issues. Such arguments build upon the fact that the EU has 'for all its political importance, traditionally focussed on essentially economic tasks, ${ }^{21}$ and that its role in social matters, such as public health, is 'weak and circumscribed.' This situation is both generated by, and illustrative of, 'the member states' lack of interest in losing control over those aspects of politics. ${ }^{23}$ Beliefs that the EU, as a supranational organisation, lacks 'technical expertise, a reputation for neutrality, superior skill and vision, greater legitimacy, [and] consistently accurate political intelligence, ${ }^{24}$ have helped to entrench the

Marsha Echols, 'Food Safety Regulation in the European Union and the United States: Different Cultures, Different Laws' (1998) 4 Columbia J Eur L 525, 525.

Case C-405/98 Konsumentombudsmannen (KO) v Gourmet International Products AB (GIP) [2001] ECR I-1816, para 21.

Echols (n 18) 528.

Greer (n 16) 134.

ibid.

ibid.

Andrew Moravcsik, The Choice for Europe: Social Purpose and State Power from Messina to Maastricht (Cornell UP 1998) 479. 
conviction that complex issues of public health should remain matters of national politics. Most Member States particularly consider the European Commission, the principal driver of EU policy, to be an inappropriate institution through which to make public health policy. This might be due, for instance, to the Commission's 'absence of budgetary resources ${ }^{25}$ in health, the fact that it is 'lacking the political authority to provide effective leadership ${ }^{26}$ in difficult social matters, and the fact that it is viewed as having 'limited expertise in the field of public health. ${ }^{27}$ Governments are unwilling to hand over responsibility for the protection of the health of their population to institutions that they feel are ill-equipped to serve their populations. From this perspective also, it is understandable why Member States would not want the EU intervening in public health.

\subsection{Arguments for giving the EU powers to intervene in public health}

While strong arguments exist for affording the EU limited or no power to act in public health, there are stronger arguments that highlight the utility of the participation of EU institutions in the discussion and formulation of public health policy, and NCD policy in particular. I argue that these reasons justify affording the EU public health powers. These arguments stem from the fact that several important factors in NCD causation are cross-border issues. Stuckler and others note that the leading root causes of NCDs are 'unhealthy commodities, their producers, and the markets that power them. ${ }^{28}$ These are all factors that have significant cross-border elements and that no single Member State is able to solve.

Multinational corporations that produce products linked to NCDs are a critical factor driving the increase in NCDs. They act as 'vectors of disease ${ }^{29}$ Dynamics of Integration' (2009) 90(5) Social Science Q 1361, 1368.

26 Laura Cram, 'Calling the Tune Without Paying the Piper? Social Policy Regulation: The Role of the Commission in European Community Social Policy’ (1993) 21(2) Policy and Politics 135, 143.

27 Sebastiaan Princen and Mark Rhinard, 'Crashing and Creeping: Agenda-setting Dynamics in the European Union’ (2006) 13(7) J Eur Public Policy 1119, 1124.

28 David Stuckler and others, 'Manufacturing Epidemics: The Role of Global Producers in Increased Consumption of Unhealthy Commodities Including Processed Foods, Alcohol and Tobacco' (2012) 9(6) PLOS Medicine e1001235, 7.

29 Anna Gilmore and others, 'Public Health, Corporations and the New Responsibility Deal: Promoting Partnerships with Vectors of Disease?' (2011) 33(1) J Public Health 2, 2. 
through relentless marketing activities and insidious exercises of power that inhibit policy efforts. ${ }^{30}$ These corporations are global entities, which make them seriously powerful-their size means that they can generate more revenue, produce larger marketing campaigns, manufacture more products, and act more consistently across markets and jurisdictions. ${ }^{31}$ Importantly, the market dominance of multinational alcohol, tobacco, fast food and other corporations means that they are able to present unified arguments in global policy discussions, which appear representative of their particular market segment, whereas groups of countries may be divided on the issues at hand. Multinationals are able to use the collective resources of the corporation in a bid to oppose national rules. They are even able to infiltrate the highest levels of political discourse simultaneously across multiple states. Such tactics are extremely difficult, in many cases impossible, for individual states to tackle alone as they are executed at the supranational level. For an effective response that will make a difference to NCD prevention, states must therefore meet these challenges at the same level. This highlights the importance of involving supranational organisations, such as the EU in public health policy.

Many of the products marketed by these corporations, particularly alcohol and unhealthy foods, are still treated as ordinary tradable commodities. ${ }^{32}$ The way in which such dual-natured commodities are allowed to circulate within markets can serve to mitigate or exacerbate the risk that they pose to public health. At present, as Sihto and colleagues note:

(...) rather than articulating how economic, industrial and trade policies could contribute to the health and wellbeing of European citizens, health policies (...) are scrutinized themselves in terms of their compliance with and contribution to industry, trade and economic policies. ${ }^{33}$

The way in which products are allowed to circulate within the European internal market can have substantial consequences for Member State public health activities.

30 Rob Moodie and others, 'Profits and Pandemics: Prevention of Harmful Effects of Tobacco, Alcohol and Ultra-Processed Food and Drink Industries' (2013) 381 The Lancet 670, 672.

31 For examples in relation to the alcohol industry, see David Jernigan, 'The Global Alcohol Industry: An Overview' (2009) 104 (Suppl. 1) Addiction 6.

32 See Thomas Babor and others, Alcohol: No Ordinary Commodity: Research and Public Policy (2nd edn, OUP 2010).

33 Marita Sihto and others, 'Principles and challenges of Health in All Policies' in Timo Stahl and others (eds), Health in All Policies: Prospects and Potentials (Eur Observatory on Health Systems and Policies 2006) 10. 
An example of this influence has recently been provided by the CJEU in its Scotch Whisky Association judgment on the implementation of minimum unit pricing for alcohol. $^{34}$ The Court in that case suggested that minimum unit pricing strategies pursuing a twofold objective of reducing alcohol consumption, specifically by harmful and heavy drinkers and generally within the population, are contrary to internal market law on the basis that less intrusive measures that attain the twofold objective equally well are available. ${ }^{35}$ Thus, due to the commodification of products, such as tobacco, alcohol and unhealthy foods, the Member States cannot avoid the fact that the operation of the internal market for goods and services will have an impact on the NCD prevention efforts within the Member States. The Member States must therefore work alongside, rather than against, the EU on how best to integrate health concerns into European level economic policy, if the operation of the European internal market is to favour the reduction of NCDs rather than to hinder it.

In summary, there are good arguments for and against affording the EU powers to contribute to public health policy-making. Member States are justifiably proud of their public health systems, are entitled to decide the level of protection they would like to secure for their population and take decisions on public health matters that affect their own nationals. However, when it comes to protecting the public from the problem of NCDs, many of the issues facing governments do not have causes that are specific to any one country's culture or traditions, do not affect solely that country's nationals, and have implications that can be similarly understood and experienced by every European. Therefore, to argue that the EU should be kept out of public health policy-making and NCD prevention in particular is to ignore the crucial transnational factors of NCD causation, which should be addressed at a transnational level. It is necessary, even if not always desirable, for the EU institutions to have some competence in public health so that they can fulfil the role they are needed to play in coordinating the transnational level response to NCDs in Europe. Having concluded that NCD prevention would benefit from the involvement of the EU, the next section turns to address the manner in which this involvement should be articulated. I will analyse the EU's current specific competence in public health and its utility in NCD prevention, as well as how the Scotland [2015] ECR I-1. 
EU's general competence to adopt rules on the functioning of the internal market has been turned to NCD prevention purposes. Through this analysis, I will aim to build a precise picture of the EU's abilities to act upon the role that it aims to, and should, play in NCD prevention.

\section{The EU's public health competence and its utility for NCD prevention}

As noted in the introduction to this piece, the EU has possessed competence in the field of public health since 1993. This section will start by explaining the complementary nature of this competence, and will proceed to analyse the powers most relevant to NCD prevention. In doing so, I hope to explore exactly how useful these powers can be to the EU.

\subsection{The complementary nature of Article 168}

The EU's current powers to act in the field of public health are contained in Article 168 TFEU, which is an area of complementary competence according to Article 6 TFEU. The nature of complementary competences was explored in 2002 by Working Group V of the European Convention as part of the preparations for drafting the Constitutional Treaty. They identified the nature of a complementary competence (which they suggested should be renamed 'supporting measures') as:

(...) treaty provisions giving authority to the Union to adopt certain measures of low intensity with respect to policies which continue to be the responsibility of the Member States. ${ }^{36}$

This understanding of complementary competence may suggest that the scope for strong action on NCDs under Article 168 is limited. Affording such a competence to the EU seemingly confirms 'the primacy of the responsibility of the [M]ember 2 March 2016. 
[S] tates in health care matters, ${ }^{37}$ and has led some to remark that ' $[t]$ here is very limited room for manoeuvre in public health law at Union level. ${ }^{38}$ However, I argue the powers held by the Union in public health can still allow the adoption of decisive and effective measures to stimulate the development of NCD policy in Europe. The fact that measures flowing from a complementary competence are of low intensity does not mean that they cannot be effective or indeed binding. Furthermore, the fact that the EU cannot create common standards itself does not mean that it cannot inspire others to create them.

\subsection{Exploring the potential of Article 168(5) TFEU}

Article 168(5) TFEU provides the most promising set of powers for future EU action on NCDs. It reads:

The European Parliament and the Council, acting in accordance with the ordinary legislative procedure (...) may also adopt incentive measures designed to protect and improve human health and in particular to combat the major cross-border health scourges (...) and measures which have as their direct objective the protection of public health regarding tobacco and the abuse of alcohol, excluding any harmonisation of the laws and regulations of the Member States. ${ }^{39}$

This is the first explicit reference to tobacco and alcohol ever made in the EU Treaties. ${ }^{40}$ This reflects the fact that the EU should be taking on increased responsibility for matters of NCD prevention to which it can contribute effectively. Article 168(5) TFEU provides the EU with important powers that can help it to achieve this. In order properly to understand the extent of these powers, three interpretative tasks must be undertaken: first, unravelling what 'incentive measures' are; second, establishing what constitutes a 'direct objective' of promoting public health; and third, understanding what 'harmonisation' of the laws and regulation of the Member States prohibits. $261,268$. Law Perspective' (2012) 19 Eur J Health L 69, 86.

39 TFEU (n 10) art 168(5).

40 Alemanno and Garde (n 15) 1760. 


\subsubsection{Understanding 'incentive measures'}

Imprecise drafting has resulted in the terms 'incentive measures' and 'measures' both being used in Article 168(5) TFEU, although it is clear that, within this particular provision, they refer to the same type of act. The preceding version, Article 152(4)(c) of the Treaty of Nice used only the term 'incentive measures' and excluded harmonisation. ${ }^{41}$ On the other hand, only the term 'measure' was used in provisions that did not exclude harmonisation. ${ }^{42}$ Thus, as Hervey and McHale point out, 'measures' were supposed to include harmonising acts, while incentive measures' were not. ${ }^{43}$ The distinction between the intensity of these two types of legislative act has been maintained in the latest version of the public health competence-Article 168(5), previously Article 152(4)(c) of the Treaty of Nice, continues to refer first of all to incentive measures. Article 168(4)(a)-(c) TFEU continues to refer to just 'measures' and, in fact, derogates from the complementary nature of the public health competence imposed according to Article 2(5) TFEU, in order to allow the possibility for harmonisation. Thus, the Treaty continues to envisage two different intensities of action. The fact that in Article 168(5) both the terms 'incentive measures' and 'measures' are used interchangeably is simply an example of poor drafting-within Article 168(5) TFEU they both refer to the same intensity of action.

Some argue that such incentive measures must be non-binding. ${ }^{44}$ Others point out that, if adopted in the form of regulations or decisions, incentive measures can be binding. ${ }^{45}$ As Grimonprez points out in the context of the EU's complementary education competence in Article 165 TFEU, if the target of the incentive is an actor within a state, then 'Member States may be obliged, first, to adapt their legislation so that beneficiaries can satisfy the conditions [to obtain the incentive] and, secondly, to take all other necessary implementing measures' that are required in order to set up the incentive. ${ }^{46}$

41 Treaty of Nice, Amending the Treaty of the European Union [2001] OJ C80/1.

42 Maastricht Treaty (n 2) art 152(4)(a) and (b).

43 Tamara Hervey and Jean McHale, Health Law and the European Union (CUP 2004) 79.

44 See, eg, Karen Heard-Laureote, 'Europeanization of Health Policy: The Role of EU Institutions' in Charlotte Bretherton and Michael Mannin (eds), The Europeanization of European Politics (Palgrave Macmillan 2013) 127.

45 Kris Grimonprez, 'The European Dimension in Citizenship Education: Unused Potential of Article 165 TFEU’ (2014) 39 Eur L Rev 3, 11. ibid 12 . 
This might be thought to conflict with the prohibition on harmonisation of Member States' laws and regulations. Grimonprez explains that this is not the case, though, because 'there is no pre-emption. Member States keep their basic competence (...) but they have to exercise it in compliance with EU law containing incentive measures. ${ }^{47}$ Harmonisation involves the substitution of national policy for European policy. Requiring Member States to comply with the imposition of 'procedural obligations to report within certain timeframes [or] provide information within certain parameters, ${ }^{48}$ for example, involves no such substitution.

The convenience of using incentive measures compared to traditional command and control legislation is also appealing to policy makers. For a start, incentive measures are 'considered ethically less problematic than coercive measures or threats, ${ }^{49}$ and thus are easier for policy-makers to justify in politically sensitive fields. Non-binding incentive measures are also attractive when negotiating policy in controversial areas for a number of further reasons, including lower contracting and sovereignty costs, accommodation of diversity, flexibility, speed and incrementalism. ${ }^{50}$

The variety of incentive measures available offers some potentially effective ways of achieving policy goals. For example, take the strongest incentive of allmoney. Since 'public health will always turn on allocational decisions, ${ }^{51}$ financial incentives are likely to have a significant impact on how health concerns are incorporated into policy design. EU level laws play 'a crucial role in legitimating the disbursement of EU funding, ${ }^{52}$ and 'although the EU's budget is modest, the EU institutions have traditionally used the provision of financial incentives to promote the integration process. ${ }^{53}$ As McKee and others note, 'even if the term "incentive measures" is interpreted as purely programmes designed to stimulate activity, if

47 ibid.

48 Tamara Hervey, 'The European Union and the Governance of Health Care' in Gráinne de Burca and Joanne Scott (eds), Law and New Governance in the EU and the US (Hart 2006) 179, 197.

49 Nancy Kass, 'An Ethics Framework For Public Health' (2001) 91(11) American J of Public Health 1776, 1780.

50 For a good summary, see David Trubek and others, "Soft Law”, "Hard Law" and EU integration' in Gráinne de Burca and Joanne Scott (eds), Law and New Governance in the EU and the US (Hart 2006) 73-74.

51 Lawrence Gostin, Public Health Law: Power, Duty, Restraint (University of California Press 2008) 493.

52 Hervey (n 47) 198.

53 ibid. 
these are accompanied by funds, as is likely, then national policies will inevitably be influenced. ${ }^{54}$ By using its own budget, and by leveraging 'the wealth of governing institutions, ${ }^{55}$ the EU can act as a 'supranational policy entrepreneur to cultivate shifts towards a particular idea, ${ }^{56}$ encouraging domestic actors to act as agents of EU policy ambition. ${ }^{57}$ The creation of structures to manage such incentives could be put in place under the powers granted by Article 168 TFEU.

Incentive measures could therefore be powerful tools for NCD policy, and should not be underestimated. As Levitt and Dubner remind us, 'people respond to incentives (...) Understanding the incentives of all the players in a given scenario is a fundamental step in solving any problem. ${ }^{58}$ Governments under political, budgetary and time constraints are more likely voluntarily to adopt courses of action that offer them appealing solutions for difficult situations, and wellconstructed incentive measures have the potential to achieve exactly this.

\subsubsection{Understanding 'direct objective'}

Article 168(5) TFEU provides authority to adopt 'measures which have as their direct objective the protection of public health regarding tobacco and the abuse of alcohol'. As yet, no case law on the interpretation of what constitutes a 'direct objective' of NCD prevention has come before the CJEU. However, alternative case law suggests that the phrase 'direct objective' allows acts to have a more substantial impact on public health than merely facilitating more effective Member State laws. In the $A B N A$ case, the CJEU gave a ruling on several measures adopted in the wake of the Bovine Spongiform Encephalopathy (BSE) crisis, which required more detailed information on the labelling of animal foodstuffs. ${ }^{59}$ These measures were justified under ex-Article 152(4)(b) of the Treaty of Nice, which allowed the EU to adopt 'by way of derogation from Article 37, measures in the veterinary and

Agnes Batory and Nicole Lindstrom, 'The Power of the Purse: Supranational Entrepreneurship, Financial Incentives, and European Higher Education Policy' (2011) 24(2) Governance: An Intl J of Policy, Administration and Institutions 311, 312.

7 For an example of how this has actually worked in the education context, with universities as the agent of EU education policy, see ibid 313.

Steven Levitt and Stephen Dubner, Think Like a Freak (Penguin 2015) 106.

Joined Cases C-453/03, C-11/04, C-12/04 and C-194/04 ABNA and Others $v$ Productschap Diervoeder [2005] ECR I-10468, para 5. 
phytosanitary fields which have as their direct objective the protection of public health. The Court held that these measures did have as their direct objective the protection of public health.

The process by which the Court arrived at this decision is instructive. The above measures were adopted following pressure on the Union to do more to prevent further outbreaks of BSE. The Court upheld their validity despite concerns over the directness of the link to protecting public health, ${ }^{60}$ and despite the Directive having been enacted against substantial opposition. ${ }^{61}$ Furthermore, the Court was willing to accept that the contested provisions of the Directive did have as their direct objective the protection of public health after merely examining the recitals of the Directive, which set out the Union legislature's rationale for the contested measures. This judgment therefore suggests that a similar margin of discretion might be afforded in relation to whether certain aspects of alcohol and tobacco control constitute direct objectives of public health-especially when the Union legislature is facing similar intense pressure to do more in alcohol control. This may afford the EU more independence in driving forward policy in the field of tobacco and alcohol control than might have been suspected under a complementary competence.

\subsubsection{Understanding 'harmonisation' of the laws and regulations of the Member States}

Two views exist on the precise meaning of 'harmonisation'. The first is that '[Union] legislation must not modify existing national public health legislation ${ }^{62}$ to the extent that Union laws 'not merely displace but replace individual national political choices. ${ }^{63}$ In other words, any EU act that substitutes policy decisions made at Member State level for those made at Union level is a harmonising act. The second interpretation is that only 'de jure ${ }^{364}$ harmonisation, which has as its direct purpose

See the concerns voiced by Davis J in the national court when the applicants originally applied for judicial review of the national implementing legislation: $R$. (on the application of ABNA Ltd and Others) $v$ The Secretary of State for Health and another [2004] 2 CMLR 39, para 51.

61 See again the background to the adoption of the directive as summarised by Davis J (n 60) paras 40-47.

62 Robert Schütze, 'Cooperative Federalism Constitutionalised: The Emergence of Complementary Competences in the EC Legal Order' (2006) 31(2) Eur L Rev 167, 181.

63 Michael Dougan, 'Legal Developments' (2010) 48 J Common Market Studies 163, 178 (emphasis added).

64 Schütze, 'Cooperative Federalism Constitutionalised' (n 62) 181. 
the homogenisation of specific national rules, should count as harmonisation for the purpose of competences that prohibit its use. Lenaerts has supported this position in the context of the Union's competence in education, arguing that if a measure has the 'indirect effect of harmonizing the content of teaching or the organization of the educational system [it] does not necessarily mean that it conflicts with the prohibition on harmonization. ${ }^{65}$

The first, wider understanding of harmonisation is supported by case law. In UK v Parliament and Council, the Court indicated that harmonisation should be understood by the term 'measures for the approximation', as it is described in the Treaties, and that the Union legislature has discretion 'as regards the harmonisation technique most appropriate for achieving the desired result. ${ }^{66}$ In view of this, we should understand 'harmonisation' as a process that encompasses a variety of methods of pre-empting national legislative initiative, all of which are intended to fall within the prohibition in Article 168(5) TFEU. Consequently, it must be concluded that the prohibition on harmonisation means that Article 168(5) TFEU confers no authority upon the EU to engage in any type of NCD prevention that would prevent the Member States from enacting their own policy on the same topic.

\subsection{Summary}

The above analysis reveals that the specific public health competence contained in Article 168(5) TFEU could be a useful and effective tool for enabling a wide range of EU action on NCDs. It should be viewed as more than just an inhibition upon the EU's ability to enact, command and control legislation. However, it is also clear that Article 168(5) TFEU could not, in its current format, accommodate all of the EU's ambitions in NCD policy, which do extend to European level standard-setting in order to drive the pace of NCD prevention. Achieving this objective is made more difficult by the fact that, no matter how many academic interpretations are proffered, the definitive meaning of Article 168(5) will remain unclear until interpreted by the CJEU. Ensuring that the EU can properly discharge the role that it is now required

66 Case C-66/04 United Kingdom v European Parliament and Council of the European Union [2005] ECR I-10574, para 45. 
to play in NCD prevention would not necessarily, however, 'require a new Treaty provision' on public health. ${ }^{67}$ Alternative legal bases are available. The next section therefore explores the use of the EU's general harmonising competence in Article 114 TFEU for just such a purpose.

\section{The EU's internal market competence and its potential for use in NCD prevention}

Responses to cross-border NCD issues are most effective when taken by states uniformly and simultaneously. In these circumstances, it would be advantageous if the EU could harmonise national laws-a good example is the work that the EU has already done in relation to cross-border tobacco advertising. However, the EU's public health competence in Article 168 TFEU does not confer a power to harmonise, so such powers must be found elsewhere in the Treaties if the EU is to fulfil its role in NCD prevention. The suitable candidate to date has been the EU's general competence to harmonise national laws for the purpose of ensuring the functioning of the internal market, a power conferred by Article 114 TFEU as follows:

The European Parliament and the Council shall (...) adopt the measures for the approximation of the provisions laid down by law, regulation or administrative action in Member States which have as their object the establishment and functioning of the internal market. ${ }^{68}$

Article 114 has already been used to bridge the EU's NCD competence gap, mainly in tobacco control, with directives being adopted on Tobacco Products and Tobacco Advertising. ${ }^{69}$ In this section, I will explore how wide a bridge the EU legislature has been permitted to build by the CJEU in its case law, and what future applications this may have in NCD prevention.

67 Cristinela-Ionela Velicu, 'Health Policy Governance in the EU: Composing a Jigsaw Puzzle?' (2011) (Suppl. 3) EUROLIMES 171, 187.

68 TFEU (n 10) art 114(1).

69 Council Directive (EU) 2014/40 concerning the manufacture, presentation and sale of tobacco and related products and repealing Directive 2001/37/EC [2014] OJ L127/1 and Council Directive (EC) 2003/33 relating to the advertising and sponsorship of tobacco products [2003] OJ L152/16. 


\subsection{The use of Article 114 TFEU for public health purposes}

The limits of the power conferred by Article 114 TFEU were first identified in a public health case, the now infamous Tobacco Advertising saga. This subsection will explain the test that was laid down, the consequences of how that test has been applied, and how any potential checks on the expansion of the competence have been side-lined by the Court.

\subsubsection{The test for recourse to Article 114 TFEU laid down in Tobacco Advertising}

The competence in Article 114 is granted to the Union for the specific purpose of building the internal market, and the Court has laid down certain conditions for its use to ensure that this purpose is respected by the EU legislature. This occurred in the Tobacco Advertising 1 case, in which Germany complained that ex-Article 100a EC, now Article 114 TFEU, provided insufficient competence for the adoption of Directive 98/43/EC which sought to prohibit the advertising and sponsorship of tobacco products in most media.

The Court in Tobacco Advertising 1 was keen to emphasise that the power in Article 114 TFEU is granted specifically for internal market building, not internal market regulation. It asserted in its judgment that:

To construe [Article 114] as meaning that it vests in the Community legislature a general power to regulate the internal market would not only be contrary to the express wording of the provisions cited above but would also be incompatible with the principle (...) that the powers of the Community are limited to those specifically conferred on it. ${ }^{70}$

The Court went on to declare that, to be based on Article 114, a Union measure must be 'intended to improve the conditions for the establishment and functioning of the internal market; ; ${ }^{71}$ must, 'genuinely have as its object the improvement of the conditions for the establishment and functioning of the internal market $;{ }^{72}$ and must 'in fact [pursue] the objectives stated by the community legislature. ${ }^{, 73}$ Thus, in ibid.

72 ibid para 84.

73 ibid para 85. 
order to rely on Article 114 TFEU, the Union legislature must show that a measure is genuinely intended to, and in fact will, improve the conditions under which the internal market functions.

The Court then added a number of qualifying statements to this test, both in Tobacco Advertising 1 and the follow up case of Tobacco Advertising 2. These included variously: that the exclusion of harmonisation in Article 168(5) TFEU 'does not mean that harmonising measures adopted on the basis of other provisions of the Treaty cannot have any impact on the protection of human health ${ }^{74}$; that 'health requirements are to form a constituent part of the Community's other policies $^{75}$ and that, provided the test for recourse to Article 114 TFEU is fulfilled, 'the Community legislature cannot be prevented from relying on that legal basis on the ground that public health protection is a decisive factor in the choices to be made.

These qualifying statements make it fairly easy to rely on Article 114 for a purpose that is not in any meaningful sense connected to internal market building. Their cumulative effect is that, as long as the positive conditions pertaining to internal market building are fulfilled, a measure relying on Article 114 as its legal basis may pursue any other objective it wants.

\subsubsection{Erosion of the limits set by Tobacco Advertising test}

This interpretation of the Tobacco Advertising test has been confirmed by its application in a string of cases that have steadily eroded the apparent rigour of the original test in Tobacco Advertising 1 to a 'threshold so apparently low and potentially subjective as to no longer guarantee that a given proposal manifests any meaningful and demonstrable connection to the internal market. ${ }^{77}$ This process will not be rehearsed in any detail here, having already been given thorough treatment in the literature dedicated to this task. ${ }^{78}$ The essential outcome, though,

75 ibid.

76 ibid para 88.

77 Dougan (n 63) 177.

78 See, eg, Dougan (n 63); Stephen Weatherill, 'The Limits of Legislative Harmonization Ten Years After Tobacco Advertising: How the Court's Case Law Has Become a "Drafting Guide" (2011) 12 German LJ 827; Paul Craig, 'The ECJ and Ultra Vires Action: A Conceptual Analysis' (2011) 48 CML Rev 395. 
has been a drastic relaxation of the Court's inquiry into whether a proposed measure actually removes any internal market barriers in practice. With each case, the Court has become increasingly prepared 'to find some connection between national disparities and the four freedoms so as to trigger Article 114, without too close an inquiry as to the reality of the impact on those freedoms. ${ }^{79}$ The effect of this case law has been that, 'provided the drafting is well-chosen, the Court has no plausible basis on which to set aside the legislative act. ${ }^{80}$ On this basis, the EU may benefit from the law-making powers in Article 114, yet is 'effectively free to base both its desire to regulate, and the actual content of that regulation, upon the pursuit of policy objectives extraneous to the establishment or functioning of the internal market. ${ }^{81}$

One might think that the primary line of defence against flagrant abuse of this power should be the application of general principles of EU law, such as proportionality and subsidiarity. However, as the analysis below will demonstrate, diligent application of these principles by the Court to the exercise of competence in Article 114 has also been sorely lacking. The Court's approach to Article 114 and proportionality was first seen in the Swedish Match case, in which the Court upheld the adoption of a total ban on the marketing of snus (an oral tobacco product) under Article 114. ${ }^{82}$ The Court held that 'only if a measure adopted in this field is manifestly inappropriate in relation to the objective' can its legitimacy be called into question. ${ }^{83}$ More recently, the Court has addressed the issue of proportionate use of Article 114 in the Vodafone case, where Article 114 was the legal basis for regulation on mobile phone roaming charges. Here, the CJEU admitted that it has:

accepted that in the exercise of the powers conferred on it the Community legislature must be allowed a broad discretion in areas in which its action involves political, economic or social choices and in which it is called upon to undertake complex assessments and evaluations. ${ }^{84}$

With this, the Court confirmed its choice to defer to the judgment of the Union legislature on all political, economic or social decisions relating to why and how

$80 \quad$ Weatherill (n 78) 828.

81 Dougan (n 63) 177.

82 Case C-210/03 Swedish Match $v$ Secretary of State for Health [2004] ECR I-11900.

83 ibid para 48.

84 Case C-58/08 Vodafone $v$ Secretary of State for Business, Enterprise and Regulatory Reform [2010] ECRI-5026, para 52. 
to use its harmonising powers, and the value of examining whether the actual reasons for resorting to harmonisation are proportionate is all but eliminated. This deference was confirmed even more recently by Advocate General Kokott in her Opinion, delivered on 23 December 2015, on the challenge brought by Poland to Directive 2014/40/EU, the revised Tobacco Products Directive. She emphasised that 'legislative competence no longer plays such a central role as it previously did. Interest is focussed on the question (...) of proportionality. ${ }^{85}$ It is disappointing, however, that she followed this up by reinforcing the Court's previous approach by declaring ' $[\mathrm{t}]$ hat discretion means that an infringement of the principle of proportionality by the Union legislature can be taken to exist only where the EU measure concerned is manifestly disproportionate. ${ }^{86}$ Thus, the Union legislature now seems to have a broad discretion in how to exercise its broad discretion, which places very few limits indeed on the use of Article 114.

Turning to subsidiarity, since the subsidiarity review can be understood as an enquiry into 'federal proportionality ${ }^{87}$ - whether the Union has been proportionate in assessing that the EU level will be the most effective for achieving the objectives sought-there is reason to suspect that the Court's lax approach to substantive proportionality in the context of Article 114 will be replicated in its approach to federal proportionality. Vodafone again provides evidence that this is indeed the case-the Court dedicates a mere two paragraphs to evaluating subsidiarity, and in similar fashion to its proportionality analysis, tamely accepts the reasoning put forward by the Union legislature in the contested Regulation itself. An actual enquiry into the added value of action at Union level was not even attempted.

This weak approach to subsidiarity is again confirmed by Advocate General Kokott. She writes that subsidiarity scrutiny 'is exercised primarily at political level, with the participation of national parliaments. ${ }^{88}$ Therefore 'the Court can reasonably review only whether the Union's political institutions have kept within the limits of the discretion conferred on them in the exercise of their competences in the light of the principle of subsidiarity. ${ }^{89}$ Thus, subsidiarity also constitutes few real checks on the Union's use of Article 114. ECLI:EU:C 2015:848, Opinion of Advocate General Kokott, para 2. ibid para 89 (emphasis in original).

87 Robert Schütze, 'Subsidiarity after Lisbon: Reinforcing the Safeguards of Federalism?' (2009) 68(3) CLJ 525, 533.

88 Case C-358/14, Opinion of Advocate General Kokott (n 84) para 146.

89 ibid para 147. 
Thus, Article 114 appears to have indeed become the general regulatory power that the Court was so at pains to prevent it from becoming. To use my earlier metaphor, as long as it uses the competence judiciously, there is now little to stop the EU from using the tools provided by Article 114 to build bridges that span the EU's NCD competence gap. Some would identify this development as an unfortunate shift in the balance of regulatory power within the EU towards the Union legislature. ${ }^{90} \mathrm{I}$ argue, though, that this can be seen as a positive result for NCD policy. The EU is under a legal obligation to ensure that all of its policies should contribute to public health protection, and that it has an increasingly important role to play in tackling the transnational causes of NCDs. To date, the EU has not always been able to fulfil these obligations. Through the judicial development of the power in Article 114, the EU now finds itself in a position to change this. In the last few paragraphs of this section, I therefore aim to explore ways in which Article 114 might be used in future NCD prevention activities.

\subsection{Potential uses of Article 114 TFEU in NCD policy}

One example of an effective NCD intervention is a ban on the marketing of products that are causal factors for NCDs, whether this consists of bans on advertising, point-of-sale display, or the sale of a product entirely. ${ }^{91}$ Advertising bans were of course the subject of the Tobacco Advertising litigation itself, with the Court clearly of the opinion, even before it set down its test, that '[i]n principle, therefore, a Directive prohibiting the advertising of tobacco products in periodicals, magazines and newspapers could be adopted on the basis of [Article 114] of the Treaty. ${ }^{92}$ The Court has also addressed more stringent marketing measures. In Swedish Match, it stated plainly that 'requiring all the Member States to authorise the marketing of the product or products concerned (...) or even provisionally or definitively prohibiting the marketing of a product ${ }^{93}$ may be an appropriate response under Article 114 to divergent national measures likely to result in trade obstacles. In Dougan and Samantha Currie (eds), 50 Years of European Treaties (Hart 2009) 93.

91 For evidence and analysis on marketing and marketing interventions, see Oliver Bartlett and Amandine Garde, 'Time to Seize the (Red) Bull by the Horns: the EU's Failure to Protect Children from Alcohol and Unhealthy Food Marketing' (2013) 38(4) Eur L Rev 498.

92 Tobacco Advertising 1 (n 70) para 98.

93 Swedish Match (n 82) para 34. 
Alliance for Natural Health and Arnold André the Court also upheld total marketing bans adopted under Article 114. ${ }^{94}$ Consequently, the adoption of marketing measures can be a legitimate exercise of Article 114. This line of case law may be especially useful in advocating for more stringent regulation of alcohol advertising by the $\mathrm{EU}$ where, as we saw above, there have been numerous calls for the $\mathrm{EU}$ to intervene to a greater extent. The case law indicates that any product may be the subject of advertising bans of varying intensity, as long as the conditions for recourse to Article 114 are met and the general principles of EU law are complied with. This suggests that the most pressing obstacle to more stringent EU action on alcohol advertising will not be a lack of competence itself, but a lack of political resolve to use the competence.

Further indications of the potential applications for Article 114 in NCD policy are provided by the recent Opinion of Advocate General Kokott in Poland $v$ Parliament and Council, where she stated that 'tak[ing] account separately of each market segment regulated in an internal market harmonisation measure (...) must be rejected. Instead, the relevant factor is whether the Directive as a whole may be based on Article 114 TFEU. ${ }^{95}$ Her Opinion indicates that Article 114 may be used to regulate a number of similar varieties of a particular class of product, while only having to show the likelihood of divergences in national laws for the product class. This may make it substantially easier to tackle novel product developments that could present threats to public health, without having to spend time specifically demonstrating the trade obstacle generated by each novel variant.

A final example of where Article 114 could be useful to future NCD prevention efforts is in the control of irresponsible practices by corporations. At present, it is difficult formally to investigate and assess the behaviour of corporations that market products such as alcohol and tobacco against international legal standards, such as the right to health. ${ }^{96}$ The ability to set up conduct scrutiny authorities for such purposes would undeniably be useful for NCD prevention efforts, and the Court has again addressed the possibility of achieving this through Article 114, albeit not in the context of public health. In the recent case of C-270/12 UK $v$ Parliament ${ }^{97}$ the

Joined Cases C-154/04 and C-155/04 Alliance for Natural Health and Others $v$ Secretary of State for Health [2005] ECR I-6485; Case C-434/02 Arnold André v Landrat des Kreises Herford [2004] ECR I-11869.

96 International Covenant on Economic, Social and Cultural Rights (adopted 16 December 1966, entered into force 3 January 1976) 993 UNTS 3 art 12. 
Court held that Article 114 supported the enactment of a Regulation that allocated certain powers to the European Securities and Markets Authority that could be used with regard to natural and legal persons. The Court stated that 'nothing in the wording of Article 114 TFEU implies that the addressees of the measures adopted by the EU legislature on the basis of that provision can only be Member States. ${ }^{98}$ Thus, on the basis of this judgment, Article 114 could potentially be used to create a corporate conduct scrutiny authority at the European level, which could monitor the compliance of corporations with international legal standards, such as the right to health, and which would then be empowered to initiate appropriate legal action should a possible infringement be found.

\subsection{Summary}

In this section, I have attempted to show that the EU's internal market competence can and has been used as a useful tool of EU NCD policy, enabling it to fulfil the role that it is needed to play in NCD prevention when the powers in Article 168 TFEU prove insufficient. The use of the powers granted by Article 114 has, however, provoked continued opposition from the Member States, showing that, although this strategy is useful from a public health standpoint, it is politically controversial. The final section of this piece discusses the relationship between Articles 114 and 168 in more detail, firstly asking how the use of one might be affected by the other, and secondly, exploring the likelihood that the Member States will agree to expand the scope of these powers.

\section{Bridging the competence gap - the relationship between Articles 168 and 114 TFEU and the likelihood of further EU public health powers}

This final section aims to argue that, while the EU can and should use both its specific and general powers in tandem in order to fulfil its responsibilities in NCD prevention, any hopes of expanding these competences in order to allow the EU to play a larger role in NCD prevention are slim, due to the lack of political desire to transfer any more powers to the EU in this sensitive social field. 


\subsection{The textual relationship between Articles 168 and 114 TFEU}

A reading of the text of the Treaty makes it clear that the EU's specific public health competence and general harmonisation competence should both be used in making public health policy. Article 168(1) provides that 'a high level of human health protection shall be ensured in the definition and implementation of all Union policies and activities, ${ }^{99}$ and Article 114(3) states that internal market harmonisation proposals concerning health 'will take as a base a high level of protection, taking account in particular of any new development based on scientific facts'. It is obvious, therefore, that the Treaties envisage that public health policy will be advanced through the use of both measures, not just through the specific public health competence. If this is the case, then we must understand the legal relationship between the two provisions, so that they may be used together in an effective way.

First, it is clear from case law that the exclusion of harmonisation in Article 168(5) applies only to use of the public health power in Article 168, and does not apply to the exercise of other powers provided by the Treaties for public health purposes. In Tobacco Advertising II, the Court clearly states that 'that provision does not mean, however, that harmonising measures adopted on the basis of other provisions of the Treaty cannot have any impact on the protection of human health. ${ }^{100}$ This point has been reinforced recently by Advocate General Kokott in another Opinion on the revised Tobacco Products Directive, this time in Phillip Morris Brands, where Advocate General has said that 'Directive 2014/40 is not a public health measure, but an internal market harmonisation measure. ${ }^{101}$ Questions of legitimacy over legislation adopted under Article 114 that has public health effects cannot be answered by referring to the construction of other competences in the Treaty. Clearly, then, the fact that the EU lacks harmonisation power for public health purposes under Article 168(5) is not relevant to the question of how the harmonisation power in Article 114 is used, and use of Article 114 for public health purposes does not constitute unconstitutional circumvention of Article

99 (emphasis added).

100 Case C-380/03 Germany v European Parliament and Council of the European Union [2006] ECR I-11631, para 95.

101 Case C-547/14 Phillip Morris Brands and Others [2015] ECLI:EU:C:2015:853, Opinion of Advocate General Kokott, para 123. 
168(5), since the two provisions are to be analysed from the perspective of two distinct mandates.

Second, it is clear that use of Article 114 for public health purposes does not require any kind of prior authorisation under Article 168. The mainstreaming provisions, cited regularly in case law on the use of Article 114, suggests that the promotion of high levels of health in other policy areas must be sought irrespective of what can and cannot be done under Article 168. For example, in British American Tobacco the Court holds specifically that Article 114(3) 'explicitly requires that, in achieving harmonisation, a high level of protection of human health should be guaranteed. ${ }^{102}$ Interestingly, Advocate General Kokott says in her Opinion in Poland $v$ Parliament and Council that 'the Union legislature had to be allowed broad discretion in respect of the assessments underlying the Directive, not least with regard to the measures which are best able to achieve the high level of health protection. ${ }^{103}$ She refers to Article 168(1) as authority for this statement, suggesting that the mainstreaming obligation there even requires the EU to use Article 114 in ways that will most effectively protect public health. It follows that recourse to Article 114 for public health purposes may be sought solely on the basis that use of the internal market competence is considered necessary to protect health, without the need to seek prior authorisation or exhaust possibilities for action under Article 168.

The legal relationship between Articles 168 and 114 is therefore such that both powers may be used independently of each other in pursuit of public health goals. Given then that either power may be used, yet Article 114 gives vastly more power, should the EU favour use of Article 114 over Article 168 in the future? There is little doubt that Article 114 TFEU offers considerable potential for developing European-level NCD policy. Article 114 occupies 'a position of unusual strength vis-à-vis the other legal bases contained in the Treaties ${ }^{104}$ and could potentially 'undermine the principle of attributed powers as regards those policy fields where dedicated Union competences are either weak or non-existent. ${ }^{105}$ This supposition is certainly relevant in the case of public health. It is therefore only natural to

102 Case C-491/01 British American Tobacco (Investments) Ltd and Imperial Tobacco Ltd [2002] ECR I-11550, para 62.

103 Case C-358/14, Opinion of Advocate General Kokott (n 84) para 88.

104 Dougan (n 63) 176.

105 ibid. 
question whether the allure of Article 114 will diminish the role of Article 168 in the development of EU-level NCD policy.

Vague as it might be, though, Article 168 is not a weak competence. As I have argued above, it has a key role to play in developing EU NCD policy-it is the only dedicated power in public health matters that the EU possesses. Moreover, since, as I will elaborate upon below, formal harmonising powers specifically for public health are not yet on the table, the new governance mechanisms that Article 168 does authorise should be seen as important tools for the EU. We must remember that, powerful as Article 114 is, it must ultimately remain tied in some way to internal market-making, which means that it must be linked in some manner to the free movement of goods, services, persons or capital. An internal market dimension is not always a necessary or desirable feature of an effective NCD policy, and there are important NCD causal factors that are unrelated to the operation of the market. Article 168 provides the necessary power to be able to adopt any measure or incentive measure that is directly relevant to protecting public health against tobacco and excessive alcohol consumption, without having to tie in secondary elements.

It would therefore be naïve to dismiss the opportunities afforded by fuller use of Article 168 simply because another way of demonstrating the competence to harmonise in pursuit of public health goals exists. There is no doubt that Article 114 is a powerful competence, and that this is surely attractive to policymakers. However, common standard setting is not always necessary for effective NCD policy, and command and control regulation that lacks proper targeting is likely to be ineffective and unpopular. Instead, we should aim to develop European-level NCD policy using both Articles 168 and 114, matching the various objectives sought to the most suitable powers to be found in either competence. It is acknowledged in the NCD literature that 'only a multi-level approach, with mechanisms ensuring the effective co-ordination between the different levels of intervention, will effectively reverse the current surge of $\mathrm{NCDs}^{106}$ - we need what both Articles 168 and Article 114 have to offer.

Having reached the above conclusions, the final question to ask in order to draw together all of the analysis conducted thus far relates to the balance of the relationship between Articles 168 and 114. For all the utility of both competences, one cannot ignore that Article 168 offers much less power than Article 114. The last section of this paper turns to examine the likelihood of the EU being able to secure 
an increase in the public health power it already holds, to lessen the pressure that is placed on the internal market competence.

\subsection{Political feeling on the use of the EU's public health competences}

Theoretically, the most elegant way in which to resolve the EU's NCD competence gap is to transfer the legislative powers that the EU is already claiming for itself under its internal market competence to the public health competence. Constitutionally speaking, this would alleviate much controversy, as the EU would be using the correct power for the correct purpose. This would take the form of a further amendment to the Treaty, furnishing the Union with greater legislative powers for the specific purpose of protecting public health. The analysis below explains, though, why the Member States are unlikely to transfer any further public health powers to the EU any time soon.

\subsubsection{Differences in public health provision between the Member States}

Practically speaking, it would be hard for the Member States ever to settle on an agreement to transfer public health competences to the EU because it is difficult to identify the precise responsibilities that should be transferred in the first place. This issue is caused by significant differences in how the Member States conceive of public health, how they provide for it, and how they finance it. Firstly, the Member States understand 'public health' very differently. Kaiser and Mackenback have conducted a survey of the use of the term 'public health' in eight EU Member States and concluded that 'a consensus on either the organization of public health or public health terminology is non-existent. Public health in Europe is characterized by the diversity of concepts, systems and terminology. ${ }^{107}$ Their study shows that eight core terms are used in varying frequencies and with various linguistic subtleties across the eight Member States. For instance, the term 'health of populations' is used primarily in Sweden and the Netherlands, ${ }^{108}$ whereas 'health promotion' was one of only two core terms that were universal to all countries. ${ }^{109}$ This diversity suggests

107 Sanja Kaiser and Johan Mackenbach, 'Public Health in Eight European Countries: An International comparison of terminology' (2008) 122 Public Health 211, 211.

108 ibid 214.

109 ibid 215. 
that it will be difficult for Member States to agree on what comprises 'public health' powers, and consequently, even more difficult to agree on a concrete set of such powers that should be transferred to the EU.

The Member States also differ considerably in their capacities for public health provision. A review for the (then) Directorate-General for Health and Consumers concluded that 'the capacity of some countries was much better developed than in others. ${ }^{110}$ For example, while only two countries were found to lack administrative units responsible for health promotion and disease prevention, seven states lacked units with responsibility for addressing socio-economic factors of public health. ${ }^{111}$ This study suggests that the abilities of Member States to act effectively in public health are different. We should therefore expect that States with more developed public health systems will be reluctant to cede any significant level of control over those systems to the EU if they feel that doing so would lower the level of protection that they could offer their own citizens.

Finally, the Member States also spend different amounts of money on public health. The Organisation for Economic Co-operation and Development figures from 2010 show that the percentage of Gross Domestic Product spent on health ranged from $6 \%$ all the way up to $12 \%,{ }^{112}$ reflecting the Member States' varying levels of ability and desire to spend on health. This generates the opposite problem to that which was indicated in the paragraph above-namely, giving further powers to the EU would result in more common standard setting, which may put pressure on some Member States with smaller health budgets. This will make those Member States unwilling to consider transferring greater powers to the EU, as they may feel that greater EU involvement in public health would force them to spend more money on public health than they can afford.

Clearly, the differences between the Member States in how public health is understood, provided for, and financed could make identifying and transferring further public health powers to the Union a difficult exercise. Despite the more flexible Treaty amendment procedure introduced at Lisbon, any revision requires unanimous agreement between the Member States. In this situation, it is extremely unlikely that all Member States would be able to agree on the nature of, and process

110 Christoph Aluttis and others, Review of Public Health Capacity in the EU (DG Health and Consumers 2013) para 13.

111 ibid 42-43.

112 OECD, 'Health Expenditure in Relation to GDP' in Health at a Glance: Europe 2012 (OECD Publishing 2012) 123. 
by which, new powers should be added to Article 168. Even if further EU powers in public health would go some way towards resolving the competence gap and that this would, in turn, result in greater protection for the health of European citizens, the level of effort required to procure unanimous agreement on what these powers should be makes such an exercise distinctly unappealing to Member States. As a result, political ambivalence has set in, the evidence of which I shall examine below.

\subsubsection{Political ambivalence to greater EU involvement in public health}

Political sentiment among the European political community is clearly against any transfer of public health legislative power to the EU. With states so unwilling to consider the issue, it is unlikely that enough momentum can be generated to force a review of the EU's public health competence. An excellent case study is the wideranging consultation exercise that the UK Government launched into the balance of competences between the UK and the EU. ${ }^{113}$ These reviews were conducted across a range of sectors, and the review conducted in the health sector reveals a significant amount about the UK Government's attitude towards EU competences in the field of health. The published results of the Health Review explicitly state that 'whilst supportive of EU work on public health in general and certain voluntary initiatives, the UK Government believes that the current balance of competence is broadly appropriate and therefore does not need to extend further. ${ }^{114}$ The report was equally conclusive on the attitudes of the (primarily) UK-based stakeholders who responded to the consultation. Although 'stakeholders strongly supported more input from the EU on public health,, ${ }^{115}$ the consultation found that 'most would prefer to see progress under existing competence. ${ }^{116}$ This shows that, in the $\mathrm{UK}$ at least, there is little appetite for a large transfer of public health competence to the EU, but rather, for increased effort on the part of the EU under its existing competences.

The absence of any desire for significant revision of the EU's public health competence is also evident from the consistency of attitudes expressed by the

113 See the announcement by Foreign Secretary William Hague at HC Deb 12 July 2012, vol 548, cols $468-70$.

114 Department of Health, Review of the Balance of Competences between the UK and the European Union: Health (Department of Health 2013) 8.

115 ibid.

116 ibid. 
holders of the rotating Presidency of the Council of Ministers. In 2000, the French presidency indicated in its priorities for public health that it would like to encourage 'closer cooperation between the Member States, with the support of the Commission. ${ }^{117}$ This view, given some three years after Article $152 \mathrm{EC}$ had been adopted, indicates satisfaction with the complementary nature of the revised competence, and a desire for the EU to continue to play a supporting role. Some 15 years later, the attitude of Member States seems not to have changed. In a recent speech to a meeting of the Committee on the Environment, Public Health and Food Safety, the Latvian health minister set out the public health priorities of the incoming Latvian Presidency. In that speech were some revealing comments on EU competence. He specifically mentioned that alcohol policy 'remains the competence of the Member States. ${ }^{, 18}$ More generally, he remarked that health 'falls within the purview of the Member States. ${ }^{, 19}$ Consequently, it appears that, even after 15 years of progressive public health action by the $\mathrm{EU}$ in the $21^{\text {st }}$ century, there is still limited appetite amongst the Member States for updating the EU's formal public health competence.

Even within the EU institutions there is ambivalence towards a transfer of public health powers. For example, a 2011 European Parliament motion calling for more action on health inequalities ${ }^{120}$ does not once mention the possibility of updating the EU's public health competence, even though various actions in public health were advocated that might benefit from an increase in EU competence, including a 'call on the Commission to mainstream an approach based on the economic and environmental determinants of health. ${ }^{121}$ Instead, there are various calls for the EU institutions to play supporting roles, for instance, a call 'on the Commission to support actions financed under the current and future Public Health Action Plans to address the social determinants of health. ${ }^{122}$ Given the minimal desire within even the European Parliament to initiate debate on

117 Dominique Guillot, 'Public Health Priorities for the French Presidency' (2000) 6(4) Eurohealth 3.

118 Speech by Guntis Belevics in the Committee on the Environment, Public Health and Food Safety, 21 January 2015 <www.europarl.europa.eu/ep-live/en/committees/video? event=201501211500-COMMITTEE-ENVI> accessed 29 August 2015.

119 ibid.

120 Committee on the Environment, Public Health and Food Safety, Report on Reducing Health Inequalities in the EU [2010] 2089 (INI).

121 ibid para 67.

122 ibid para 70. 
competence reform in public health, it is difficult to see where large-scale political momentum would come from for initiating a serious review of the EU's public health competence.

In summary, political feeling is that the current powers of the EU in public health are sufficient, and that greater and more effective use should be made of the specific complementary competence already conferred upon the EU in public health. If this much was not clear from remarks in political discourse, it is certainly obvious from the recent legal challenges to the EU's revised Tobacco Products Directive-adopted under Article 114-on the grounds of lack of competence, which were examined above. This actually leaves the EU in a slightly awkward position since the EU's specific competence might still be considered too vague to allow the EU to step up its involvement in public health as desired by the political community. With the Member States unwilling to extend, or perhaps even to clarify, the powers in Article 168, the EU will continue to experience a conflict between its powers and its ambitions in NCD policy, and will continue to have reason to turn, not to Article 168, but to Article 114. Thus, the competence gap between the EU's ambitions and its powers in public health looks set to be maintained.

\section{Concluding remarks}

There are strong reasons why the EU should be involved in the fight against NCDs. The transnational nature of many of their most important root causes means that there must be some form of transnational response, and the EU is well placed to coordinate and perhaps at times even lead this response. The competences given to the EU in order to carry out this role provide a considerable amount of law-making power. They are not, however, without their weaknesses and vagaries. Despite the potential of Article 168, its already well-known limits as a complementary competence remain, as do uncertainties surrounding the newly added powers on tobacco and alcohol. Where these limits are reached, Article 114 TFEU provides the necessary authority for the EU to drive NCD policy forward. However, as recent case law demonstrates, the appropriateness of this strategy is still highly contested and thus, still politically challenging to employ.

It is evident, though, that the Member States would find it difficult to agree upon how to establish a stronger legal basis from which the EU could pursue its ambitions in NCD prevention, or at least, to clarify the ambiguities in its current legal basis for public health. This is disappointing, as effort expended now in order to clarify exactly what the EU should and should not be doing in NCD prevention 
may prevent the competence gap from becoming any more unstable. At present, realising the potential of Article 168 would still not be enough to accommodate the EU's ambitions in NCD prevention. The EU is clearly not afraid to use Article 114 in order to bridge this gap, and nor should it be, as the internal market competence offers a legitimate outlet that enables the EU to play its part in the multi-level approach that is required for effective NCD prevention. However, as long as the $\mathrm{EU}$ is willing to use Article 114 in this manner, it seems from the proliferation of case law that one or more Member States will always be willing to challenge such use. This pattern surely cannot be sustainable. The outcome of the next challenge may do more to upset the balance of competence between the Member States and the EU than if the Member States made the effort required clearly to establish the specific powers that the EU needs in order freely to play its part in NCD prevention.

If we are to expect the Member States to make efforts to resolve the current competence gap, the EU must first make efforts to demonstrate that it still exists. Thus, the first step must be for the EU to answer the calls of the Member States (and others) for more effective action in key areas of NCD prevention, making full and effective use of Article 168, which still holds untapped potential for European level NCD policy. Only then will it be possible to demonstrate the necessity of albeit carefully limited, public health harmonisation powers that will enable the EU to fulfil its role in the field of NCD prevention. 